\title{
DESIGN OF SCC MIXES BASED ON CEMENT - SP COMPATIBILITY
}

\section{STUDIES}

\author{
Sayeed Ashar ${ }^{1}$, S.Suresh ${ }^{2}$ N. Nanjundappa ${ }^{3}$, J.K.Dattatreya ${ }^{4}$ \\ ${ }^{1}$ Post Graduate Student, ${ }^{2}$ Assiocate Professor, ${ }^{3}$ Assistant Professor, ${ }^{4}$ Research Professor, Department of Civil \\ Engineering, Siddaganga Institute of Technology, Tumkur. \\ ashar.ashu786@gmail.com, siddalingaiah.suresh@gmail.com,nanjundappa60@gmailcom,jk.dattatreya@gmail.com
}

\begin{abstract}
In this work 4 superplasticizers were used and on the basis of the workability test on cement paste two SP's were selected for further studies and to compare their effects on mortar properties such as workability, compressive strength, water reduction and tensile strength. Two different mortar mixes (1:1.5 \& 1:2) were tested for three values of $w / c$ ratio $(0.3,0.35$, and 0.4$)$ for varying SP dosage i.e. from 0.6 to $2 \%$. This paper presents an experimental investigation on strength aspects such as compressive, and split tensile strength of self compacting concrete containing fly ash and workability tests (slump flow, $T_{500 \mathrm{~mm}}$, V-Funnel and $T_{5 \mathrm{~min}}$ ) are carried out. The methodology adopted is that Portland cement is replaced by 0\%, 35\% and 50\% of fly ash using two types of superplasticizers (SNF, PCE) and performance is measured and compared.
\end{abstract}

Further Design of Self Compacting Concrete by replacing Fly ash is proposed and the studies on fresh and hardened properties were conducted. The results showed that PCE type Superplasticizer is performing better than SNF type in terms of workability.

Keywords: Cement, Super plasticizers, mortar, SCC, Fly ash, fresh and hardened properties, compressive strength, split tensile strength.

\section{INTRODUCTION}

Concrete occupies unique position among the modern construction materials, Concrete is a material used in building construction, consisting of a hard, chemically inert particulate substance, known as a aggregate (usually made for different types of sand and gravel), that is bond by cement and water. Self-compacting concrete is a fluid mixture suitable for placing in structures with congested Self Compacting Concrete is innovative concrete which can reduce the amount of cementitious materials and total volume of concrete required. It is a fluid mixture which can flow under its own weight, completely filling formwork and achieving full compaction in structures even with congested reinforcement. Also the use of SCC increases the speed of construction and reduces the noise. If the mineral admixtures replace a part of the Portland cement, the cost of self-compacting concrete will be reduced especially if the mineral admixtures are waste or industrial by-product such as fly ash which is a by-product of the combustion of pulverized coal in thermal power plants. Therefore use of fly ash not only provides economical benefits but also reduces heat of hydration Henceforth replacing of Portland cement with fly ash can reduce the production of $\mathrm{CO} 2$. Addition of SP reduces the water content of the concrete which leads to higher durability, in addition to better mechanical integrity of the structure. The successful production of self - compacting concrete (SCC) for use, is depended on arriving at an appropriate balance between the yield stress and the viscosity of the paste.

In The present study 4 superplasticizers were used and on the basis of the workability test on cement paste two SP's were selected for further studies and to compare their effects on mortar properties such as workability, compressive strength, water reduction and tensile strength. Two different mortar mixes $(1: 1.5 \& 1: 2)$ were tested for three values of w/c ratio $(0.3,0.35$, and 0.4$)$ for varying SP dosage i.e. from 0.6 to $2 \%$. This paper presents an experimental investigation on strength aspects such as compressive, and split tensile strength of self compacting concrete containing fly ash and workability tests (slump flow, T500mm, V-Funnel and T5min) are carried out. The methodology adopted is that Portland cement is replaced by $0 \%, 35 \%$ and $50 \%$ of fly ash using two types of superplasticizers (SNF, PCE) and performance is measured and compared. Further Design of Self Compacting Concrete by replacing Fly ash is proposed and the studies on fresh and hardened properties were conducted. The results showed that PCE type Superplasticizer is performing better than SNF type in terms of workability. The mixes are designed as per EFNARC guidelines to meet the requirement of self compacting concrete. The mixes belong to class 2 as per Walraven's classification, which is adopted by EFNARC for self compatibility. 
Cement exhibit variable characteristics depending on the location and quality of raw material, manufacturing processdry/wet, grinding and temperature. Varieties of SP's with different physical and chemical properties are available in the market. As a result there will be variability in interaction with different cement and SP's that can have an adverse effect on flash setting, delayed setting, rapid slump loss, improper strength gain, inordinate cracking etc. collectively called as incompatibility of cement -SP combination. This can be assessed only by an experimental investigation. Therefore for every brand and batch of cement compatible SP combination should be identified based on test. The variation of SP on cement can vary from batch to batch of cement and for different SP's. In the present study there are four types of superplasticizer's are used two of them are Sulphonated naphthalene formaldehyde based i.e. (Rheobuild 1125,
Conplast 430) and other two were Polycarboxylate ether type F (Auramix 400, Glenium 6100).on the basis of workability test on cement paste two SP's were selected for further studies as shown in figure 2 and figure 3. In this study three types of Sand were used i.e. Natural sand (N1), Natural sand (N2) and Manufactured sand (M). The texture of sand is shown in figure 6. On the basis of the workability test we shortlisted Manufactured Sand for further studies as shown in table 5.

\subsection{Scope of the Study}

The main aim of the project is to select the SP type and dosage required from compatibility studies based on the tests. Design of SCC mixes for selected range of control parameters, so as to achieve the target performance characteristics .Study of fresh and hardened properties of concrete

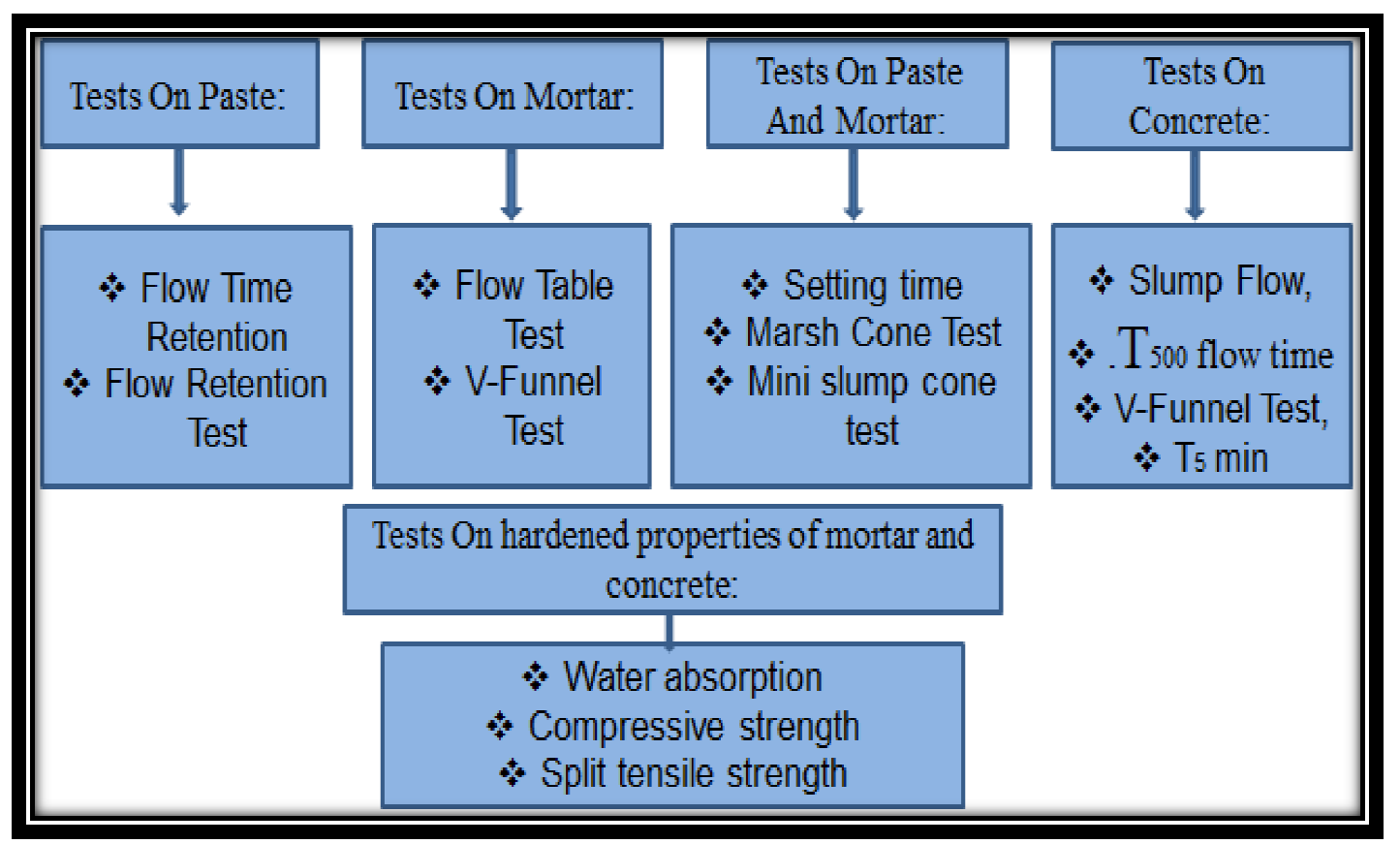

Fig.1 Scope of the study

\section{METHODOLOGY AND MATERIALS:}

The materials used for this study includes: Polycarboxylate ether and sulphonated naphthalene formaldehyde based superplasticizer complying with ASTM C-494 type F, was used.

\subsection{Materials Used}

\subsubsection{Cement}

Ordinary Portland cement (Grade 53) was used. Its physical properties are as given below.
Table 1 physical properties of cement

\begin{tabular}{|l|l|l|}
\hline Properties & Results obtained & $\begin{array}{l}\text { IS:8112-1989 } \\
\text { specification }\end{array}$ \\
\hline Fineness & 9 & $10 \mathrm{~mm}$ \\
\hline Consistency & $28 \%$ & - \\
\hline $\begin{array}{l}\text { Initial setting } \\
\text { time }\end{array}$ & $105 \mathrm{~min}>$ & $30 \mathrm{~min}$ \\
\hline Final setting time & $310<$ & $600 \mathrm{~min}$ \\
\hline Specific gravity & 3.15 & - \\
\hline
\end{tabular}




\subsubsection{Fly Ash:}

Class F Fly ash obtained from "Raichur Thermal Power Station, Karnataka state, India. The physical and chemical properties of fly ash are given in the above Table 2 respectively.

Table 2 Chemical properties of Fly ash

\begin{tabular}{|l|l|l|}
\hline S1 No & Properties & Results \\
\hline 1 & silica & 58.58 \\
\hline 2 & Iron oxide & 3.42 \\
\hline 3 & alumina & 28.2 \\
\hline 4 & $\mathrm{CaO}$ & 2.23 \\
\hline 5 & $\mathrm{MgO}$ & 0.32 \\
\hline 6 & $\mathrm{SO} 3$ & 0.07 \\
\hline 7 & Alkalies(K2O) & 1.26 \\
\hline 8 & $(\mathrm{Na} 2 \mathrm{O})$ & 0.58 \\
\hline
\end{tabular}

\section{TESTS ON MATERIALS}

Constituents of the concrete mix namely the coarse aggregate (granite), fine aggregate (sharp sand), and cement (Ordinary Portland cement), water and chemicals. The granite used was well graded, free from unwanted particles and of $12.5 \mathrm{~mm}$ and $20 \mathrm{~mm}$ sizes while the sharp sand consisted of $5 \mathrm{~mm}$ sized particles on average. The tests carried out include tests on the coarse (granite) aggregates, sieve analysis of the fine (sharp sand) aggregate, workability tests, and crushing test on the concrete cubes. The sieve analyses of the coarse aggregates and fine aggregates (sand) are given in Table 3. The size of aggregates was between 4.75 to $9.5 \mathrm{~mm}$. The water absorption of the aggregate was $18.02 \%$, and the fineness modulus of the sand was 2.76 , specific gravity was 2.68 , and absorption value was 2.94. Type II Portland cement was used in all mixes with a specific gravity of 3.15 . The $0 \%, 35 \%$ and $50 \%$ fly ash by mass of cementitious materials as cement replacement was used. A polycarboxylic ether (PCE) and sulphonated napthelene formaldhyde (SNF) superplasticizer was incorporated in all mixture; the PCE used was in the liquid form with a specific gravity of 1.13 and solid content of $38.4 \%$. where as SNF used was with specific gravity 1.22 and solid content of 42.8 . To enhance the stability of SCC also filler (lime stone powder) with the nominal particle size of 0.15 and $0.3 \mathrm{~mm}$ was used. sand, lime stone powder, cement, and fly ash were mixed first for $1 \mathrm{~min}$, and then Superplasticizer that was mixed in water was added (due to high value of water observation. several attempts were made to find out the way of adding SP and water content of the mixture, and finally it was found that the SP mixed in total water is a good solution when one is used aggregate in the SCC). Then all the materials were mixed for 2 to 4 minutes. Several design procedure based on scientific theories or (1) empirical experience have been proposed for normal SCC [1]. In general, these procedures fall into the following two categories: (1) combination of superplasticizer and high content of mineral powders and (2) combination of superplasticizer. Table 3 gives the gradation of sands and Table 4 gives the gradation of coarse aggregate.

Table 3 Fine aggregate gradation

\begin{tabular}{|l|l|l|l|l|l|}
\hline $\begin{array}{l}\text { sieve } \\
\text { size in } \\
\mathrm{mm}\end{array}$ & \multicolumn{5}{|l|}{ Percentage of passing } \\
\cline { 2 - 6 } & $\begin{array}{l}\text { Upper } \\
\text { limit }\end{array}$ & $\begin{array}{l}\text { Lower } \\
\text { limit }\end{array}$ & $\begin{array}{l}\text { N1 } \\
\text { sand }\end{array}$ & $\begin{array}{l}\text { N2 } \\
\text { sand }\end{array}$ & $\begin{array}{l}\text { M- } \\
\text { sand }\end{array}$ \\
\hline 0.15 & 10 & 0 & 2.8 & 1.4 & 2.2 \\
\hline 0.3 & 30 & 8 & 10 & 2.8 & 26.6 \\
\hline 0.6 & 59 & 35 & 37 & 39.4 & 55.8 \\
\hline 1.18 & 90 & 55 & 73.8 & 89 & 67.8 \\
\hline 2.36 & 100 & 75 & 85 & 100 & 80 \\
\hline 4.75 & 100 & 90 & 100 & 100 & 100 \\
\hline
\end{tabular}

Table 4 Coarse aggregate gradation

\begin{tabular}{|c|c|c|c|c|}
\hline sieve size & $\begin{array}{l}\text { Ypassing } \\
\text { 20mm }\end{array}$ & $\begin{array}{l}\text { Yppassing } \\
12.5 \mathrm{~mm}\end{array}$ & $\begin{array}{l}60 \% 20 \mathrm{~mm} \& \\
400 \% 12.5 \mathrm{mmm}\end{array}$ & $\begin{array}{c}\text { is 383-1970 grading } \\
\text { limits for CA }\end{array}$ \\
\hline 20 & 91.84 & 100 & 955,09 & 955:100 \\
\hline 10 & 2.02 & 88.19 & 36.84 & 25.55 \\
\hline 4,75 & 0 & 3.81 & 1.83 & 0.10 \\
\hline
\end{tabular}




\subsection{Test on Mortar}

Table 5 V-funnel test on M-sand Mini slump cone test on cement paste

\begin{tabular}{|l|l|l|l|l|l|l|}
\hline w/c & $\mathrm{s} / \mathrm{c}$ & $\begin{array}{l}\% \\
\mathrm{SP}(\mathrm{SNF})\end{array}$ & $\begin{array}{l}\text { Flowin } \\
\mathrm{sec}\end{array}$ & $\mathrm{s} / \mathrm{c}$ & $\begin{array}{l}\% \\
\mathrm{SP}(\mathrm{PCE})\end{array}$ & $\begin{array}{l}\text { Flowin } \\
\mathrm{sec}\end{array}$ \\
\hline 0.3 & 1.5 & $1.9 \%$ & 34 & 1.5 & $1.4 \%$ & 24 \\
\hline 0.35 & 1.5 & $1.7 \%$ & 20 & 1.5 & $1.1 \%$ & 14 \\
\hline 0.4 & 1.5 & $1.4 \%$ & 15 & 1.5 & 0.8 & 9 \\
\hline 0.3 & 2 & $2 \%$ & 52 & 2 & $1.6 \%$ & 36 \\
\hline 0.35 & 2 & $1.8 \%$ & 26 & 2 & $1.3 \%$ & 17 \\
\hline 0.4 & 2 & $1.6 \%$ & 18 & 2 & $0.9 \%$ & 11 \\
\hline
\end{tabular}

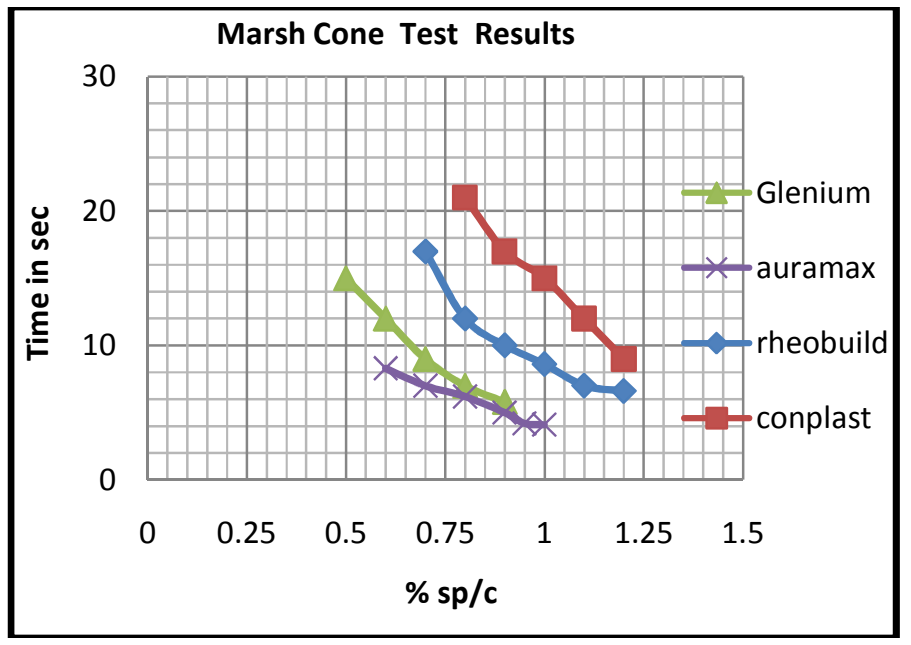

Fig.2 Marsh Cone Test for different SP's

Table 6 Flow table test on M-sand

\begin{tabular}{|l|l|l|l|l|l|l|}
\hline & & $\begin{array}{l}\% \\
\text { SP } \\
\text { (SN } / \mathrm{c}\end{array}$ & $\begin{array}{l}\text { Sprea } \\
\text { d in } \\
\mathrm{cm}\end{array}$ & $\begin{array}{l}\mathrm{F}) \\
\mathrm{s} / \mathrm{c}\end{array}$ & $\begin{array}{l}\text { SP(PCE } \\
\text { SP }\end{array}$ & $\begin{array}{l}\text { Spre } \\
\text { ad in } \\
\mathrm{cm}\end{array}$ \\
\hline 0.3 & 1.5 & 1.9 & 19.5 & 1.5 & 1.4 & 21.5 \\
\hline 0.35 & 1.5 & 1.7 & 23 & 1.5 & 1.1 & 24 \\
\hline 0.4 & 1.5 & 1.4 & 25.5 & 1.5 & 0.8 & 26 \\
\hline 0.3 & 2 & 2 & 18 & 2 & 1.6 & 18 \\
\hline 0.35 & 2 & 1.8 & 22 & 2 & 1.3 & 22.5 \\
\hline 0.4 & 2 & 1.6 & 24 & 2 & 0.9 & 25.5 \\
\hline
\end{tabular}

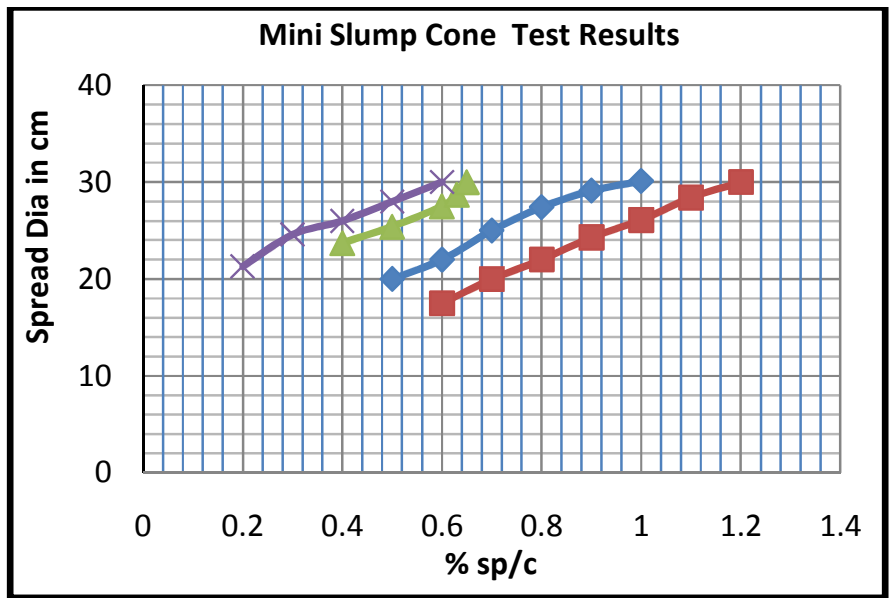

Fig. 3 Mini Slump Cone Test for different SP's

Table 7: Mini slump cone test on different Sands: $4.75 \mathrm{~mm}$ $0.075 \mathrm{~mm}$

\begin{tabular}{|r|r|r|r|r|}
\cline { 3 - 5 } \multicolumn{2}{c|}{} & \multicolumn{3}{c|}{ Spread in cm } \\
\hline W/c & Sp/C & N1 sand & N2 sand & M sand \\
\hline 0.4 & $1 \%$ & 18 & 8 & 9 \\
\hline 0.4 & $1.20 \%$ & 19 & 8.8 & 10.1 \\
\hline 0.4 & $1.40 \%$ & 20.2 & 9.4 & 10.9 \\
\hline 0.4 & $1.60 \%$ & 21.4 & 10.1 & 12.6 \\
\hline 0.4 & $1.80 \%$ & 22.1 & 12.1 & 13.9 \\
\hline 0.4 & $2 \%$ & 23.5 & 14 & 15.2 \\
\hline
\end{tabular}

Table 8: Results of Fresh properties of SCC

\begin{tabular}{|l|l|l|l|l|l|}
\hline $\begin{array}{c}\text { Sl } \\
\mathrm{N}_{0}\end{array}$ & $\begin{array}{c}\text { Cement } \\
\text { replaced }\end{array}$ & $\begin{array}{c}\text { Slump } \\
\text { flow } \\
\mathrm{mm}\end{array}$ & $\begin{array}{l}\mathrm{T} \text { 500mm } \\
\text { sec }\end{array}$ & $\begin{array}{c}\mathrm{V}- \\
\text { funnel } \\
\text { sec }\end{array}$ & $\begin{array}{c}\mathrm{T} \\
5 \mathrm{~min} \\
\text { sec }\end{array}$ \\
\hline 1 & $0 \% \mathrm{FA}$ & 680 & 2 & 6 & 8.5 \\
\hline 2 & $35 \% \mathrm{FA}$ & 630 & 4 & 10 & 13 \\
\hline 3 & $50 \% \mathrm{FA}$ & 610 & 5 & 12 & 15 \\
\hline
\end{tabular}




\subsection{Texture of Sand:}

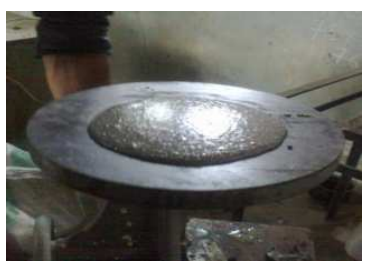

Fig.4 Flow table

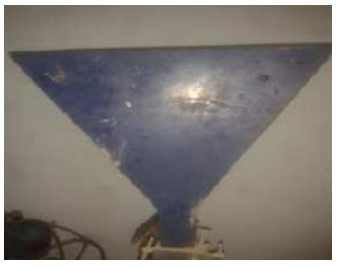

Fig.5 V-funnel N1- sand

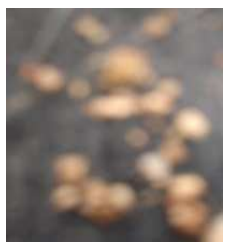

N2-sand

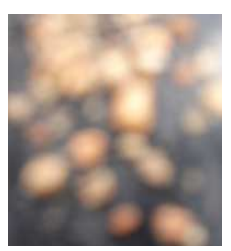

M-sand

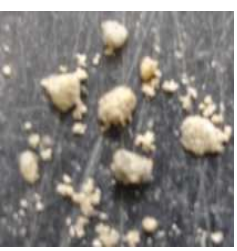

Fig.6 Texture for Different Sands

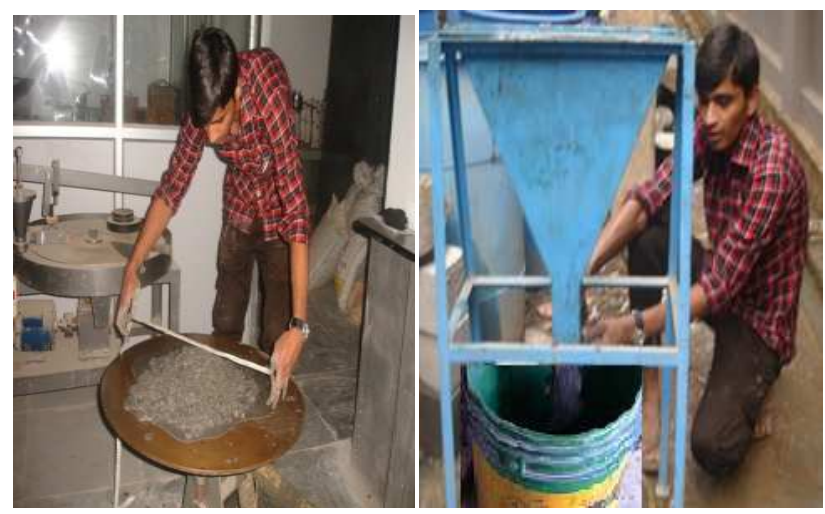

Slump flow test

V-funnel test

Fig.7 Workability test on concrete

$\mathrm{T}_{500 \mathrm{~mm}}$ : time taken for concrete to reach the $500 \mathrm{~mm}$ spread circle.

$\mathrm{T}_{\mathrm{f}} \quad$ : V-funnel flow time after keeping the concrete in funnel for $10 \mathrm{sec}$.

$\mathrm{T}_{5 \min } \quad$ : V-funnel flow time after keeping the concrete in funnel for $5 \mathrm{~min}$.

The flowability of the fresh concrete can be tested with the Vfunnel test, whereby the flow time is measured, figure 8.The funnel is filled with about 12 litres of concrete and the time taken for it to flow through the apparatus is measured. Further, T5minis also measured with V-funnel, which indicates the tendency for segregation, wherein the funnel can be refilled with concrete and left for 5 minutes to settle. If the concrete shows segregation, the flow time will increase significantly.

\section{WORKABILITY TEST ON THE MORTAR AND CONCRETE}

A total of 108 cubes were cast comprising of control cubes and cubes containing $0.9 \%$ to $1.2 \%$ SP by weight of cement. A mix ratio of $1: 1.5: 2.4$ (that is $1.65 \mathrm{~kg}$ of cement, $2.47 \mathrm{~kg}$ of sand and $3.96 \mathrm{~kg}$ of granite) was used to produce the selfcompacting concrete. For mortar, total of 144 cubes were cast comprising of control of cubes and cubes containing $0.6 \%$ to $2 \%$ SP by weight of cement. This was batched by weight. After the mixing of the batched material, water was added and mixed thoroughly with shovel to achieve a homogenous mix and then the cubes were moulded (figure 9) and cured in a curing tank for the durations as shown in Table 1.

\subsection{Testing of Samples}

To study the effect of addition of the superplasticizers on the workability, compressive strength, water absorption and tensile strength the following tests procedures used. Crushing tests were performed on the mortar, concrete cubes to determine their compressive strengths. After curing for 3, 7, and 28 days and Split cylinders tests were used to check the tensile strength of mortar and concrete mixes at 28 days of age. The load was applied to the cubes through hydraulic operation of the machine until failure occurred. The corresponding peak load and stresses at this point were recorded and used to determine the average compressive strength. 


\subsection{Compressive Strength of Mortar and Concrete}

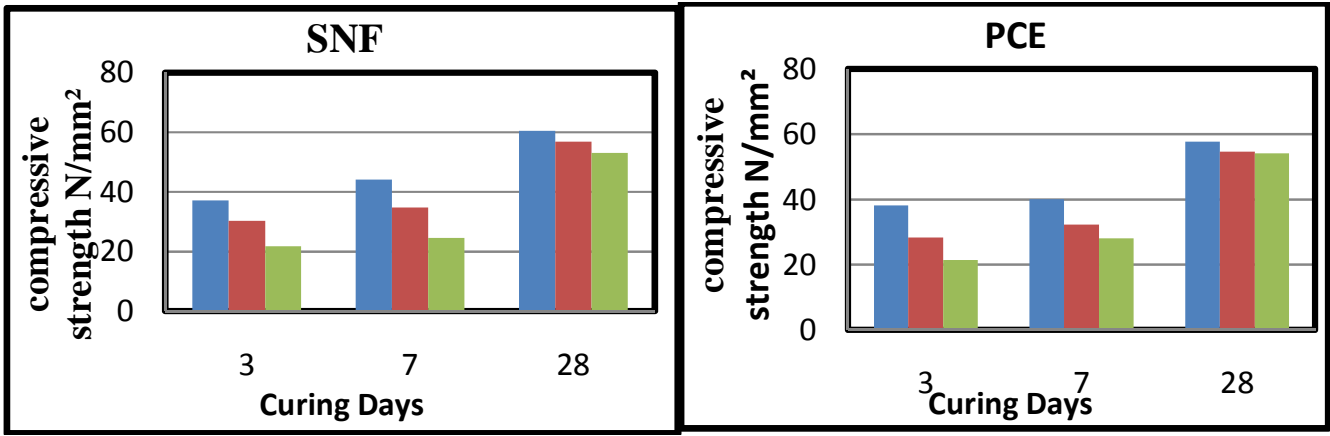

Figure 8: Compressive strength V/s curing days for mortar mix of 1:1.5 cement sand ratio

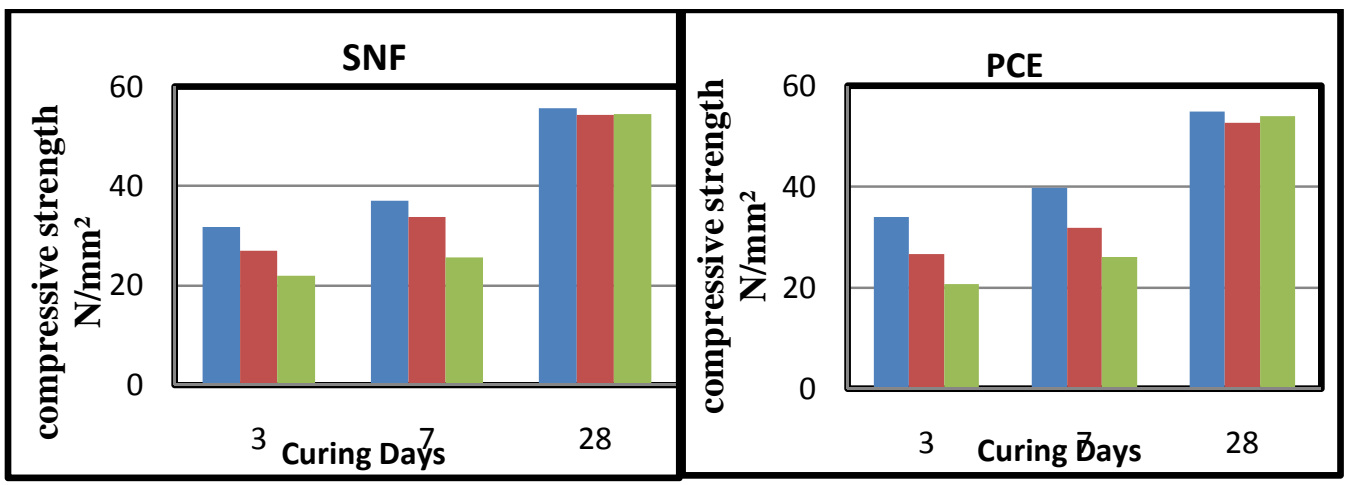

Figure 9: Compressive strength $\mathrm{V} / \mathrm{s}$ curing days for mortar mix of 1:2 cement sand ratio

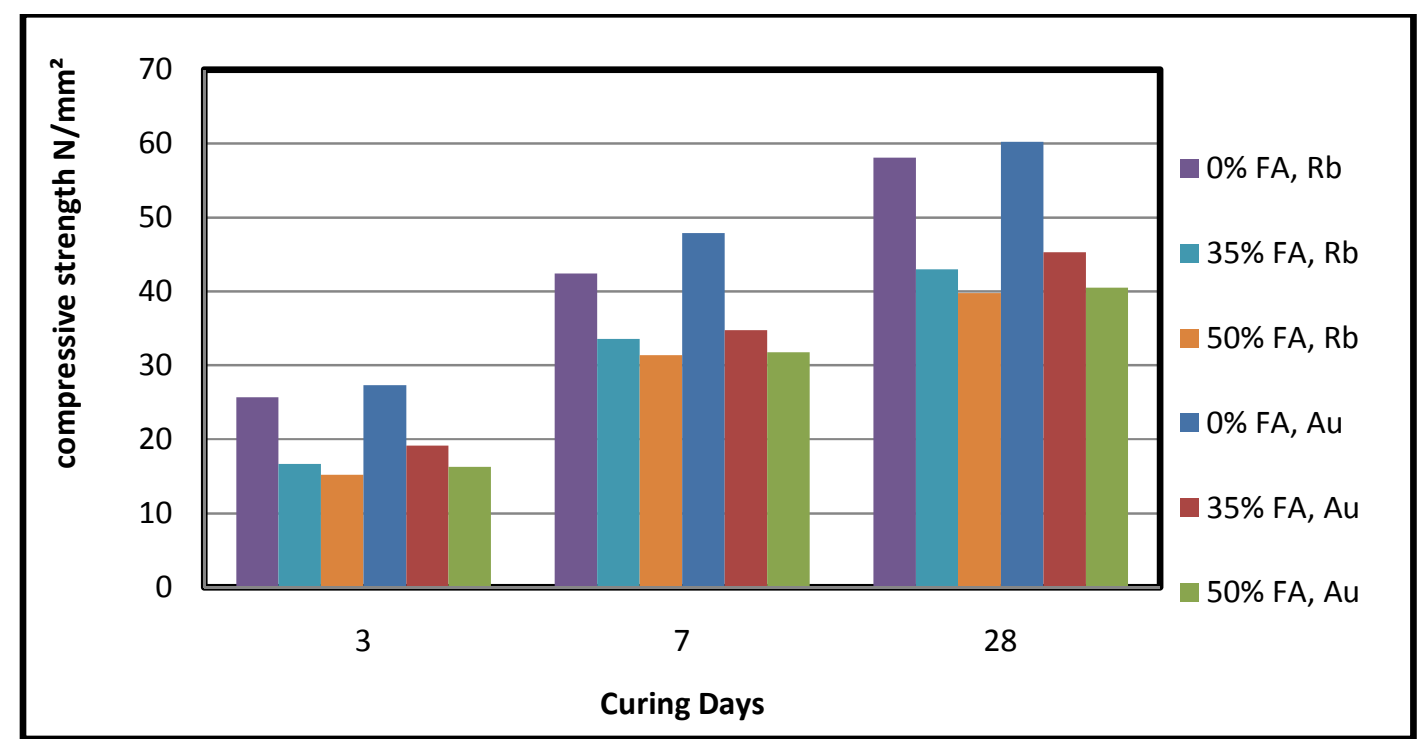

Figure 10: comparison of compressive strength of concrete Vs curing days 


\section{SPLIT TENSILE STRENGTH OF MORTAR AND CONCRETE:}

Table 9 Tensile strength of mortar

\begin{tabular}{|c|c|c|c|c|c|c|c|}
\hline \multirow{2}{*}{$\begin{array}{l}\text { Cure } \\
\text { days }\end{array}$} & \multirow{2}{*}{$\begin{array}{l}\text { C:S } \\
\text { Ratio }\end{array}$} & \multicolumn{6}{|c|}{ Split tensile strength $\mathrm{N} / \mathrm{mm}^{2}$} \\
\hline & & \multicolumn{3}{|c|}{ SNF } & \multicolumn{3}{|c|}{ PCE } \\
\hline \multirow{3}{*}{$\begin{array}{c}28 \\
\text { days }\end{array}$} & \multirow[b]{3}{*}{$1: 1.5$} & \multicolumn{3}{|c|}{$\mathrm{w} / \mathrm{c}$} & \multicolumn{3}{|c|}{$\mathrm{w} / \mathrm{c}$} \\
\hline & & 0.3 & 0.35 & 0.4 & 0.3 & 0.35 & 0.4 \\
\hline & & 4.4 & 4.05 & 4.3 & 4.8 & 3.8 & 3.7 \\
\hline $\begin{array}{c}28 \\
\text { days }\end{array}$ & $1: 2$ & 3.7 & 3.6 & 3.5 & 4.6 & 3.6 & 3.6 \\
\hline
\end{tabular}

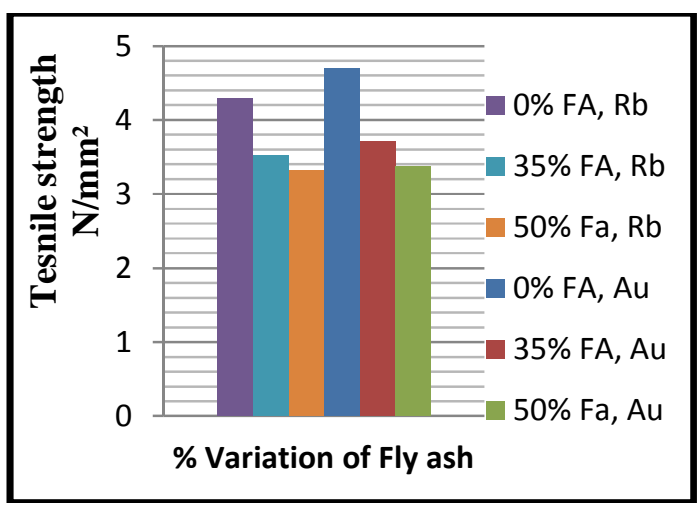

Fig.11 Tensile strength of Concrete

\section{MIX-DESIGN}

The Japanese concept for design of SCC is based on a method proposed by Okamura and Ozawa [2]. The authors have proposed a simple mix-proportioning system assuming general supply from ready-mixed concrete plants. The coarse and fine aggregate contents are fixed so that selfcompactability can be achieved easily by adjusting the water to powder volume ratio and superplasticizer dosage only. The mixed design as proposed is:

- Coarse aggregate content is fixed at $50 \%$ of the solid volume;

- Fine aggregate content is fixed at $40 \%$ of the mortar volume;

- Water-powder ratio in volume is assumed as 0.9 to 1.0 depending on the properties of the powder; and

- Superplasticizer dosage and the final water-powder ratio are determined so as to ensure the self-compactability.

The value of water to powder volume ratio $(\mathrm{Vw} / \mathrm{Vp})$ is optimized by mortar flow test and Mortar Funnel Test.

Takada [3] considered the slump flow value of $650 \pm 30 \mathrm{~mm}$ and the V-funnel time of $11 \pm 2 \mathrm{~s}$ as adequate value for the workable SCC.

\section{CONCLUSIONS}

As a result of this experimental study, the following conclusions could be made: The workability of Mortar depends mainly on the type of SPs used. In this study Polycarboxylate based and Napthelene based SP's are used, especially PCE, showed better results in improving the workability of Mortar, as determined by both of the workability tests. The chemical admixtures adversely affect the setting time of mortars. Among the mineral admixtures, however, PCE based SP increased the setting time of the mortars.

\section{Concrete}

The observations and test results have revealed that the properties of self compacting Concrete in fresh and hardened stages have been improved with the addition of both types of Superplaticiser's for all nominal mixes of concretes. The contributions of Polymer based SP are however more pronounced in terms of increase in the compressive strength, workability and reduction in the water requirements of concretes. It could be concluded that, workability of SCC has been increased significantly with the addition of SP. Obtained results indicated that increasing dosage of SP to $2.0 \%$ by weight of cement improved the performance of concrete and contributed more to the improvement of its transportability properties, but at the same time has considerably reduced water/cement (W/C) ratio. On the basis of the studies carried out on concrete, it can be concluded that:

$>$ The proper selection of superplasticizer is necessary, which should be compatible with the cement used.

$>$ The amount of water reduction increases with the dosage of superplasticizer. However the slump flow increases with the decrease in elapse time when the dosage of superplasticizer is higher.

$>$ At the water/powder ratio of 1.180 to 1.215 , slump flow test and V-funnel test results were found to be satisfactory, i.e. passing ability, filling ability and are well within the limits.

> Trail mixes have to be made for maintaining flowability, self compatibility and obstruction clearance.

$>$ Almost all the mixtures produced belonged to class 2 as per Walraven's classification, which is adopted by EFNARC.

$>$ By using the OPC 53 grade, normal strength of $40 \mathrm{MPa}$ to $60 \mathrm{MPa}$ at 28-days was obtained, keeping the cement content around $225 \mathrm{~kg} / \mathrm{m}^{3}$ to $450 \mathrm{~kg} / \mathrm{m}^{3}$.

$>$ From the observations it was found that nearly half of the compressive strength is gained in 3 days and $2 / 3 \mathrm{rd}$ of the strength in 7 days curing which satisfies IS: 456-2000.

$>$ The compressive and tensile strength of superplasticized SCC concrete are higher than those of conventional concrete of the same consistency. The test results were found to be within the prescribed limits. 


\section{REFERENCES}

[1] "EFNARC (European Federation of national trade associations representing producers and applicators of specialist building products)" (2002), Specification and Guidelines for self-compacting concrete, Hampshire, U.K.

[2] K Ozawa, M Kunishima, K Maekawa and K Ozawa, (1989) "Development of High Performance Concrete Based on Durability Design of Concrete Structures". Proceeding of East-Asai and Pacific Conference on Structural Engineering and Construction (EASEC-2), vol:1, pp. 445-450.

[3] K Takada, G I Pelova and J C W Walraven, (1999) "Influence of Chemical Admixtures and Mixing on the Mix Proportion of General Purpose Self-Compacting Concrete". International Congress 'Creating with Concrete', University of Dundee, UK, September pp. 610 .

[4] Khayat K.H, Ghezal A, (1999) "Utility of Statistical models in Proportioning Self-Compacting Concrete", Proceedings, RILEM International symposium on SelfCompacting Concrete, Stockholm, pp. 345-359.

[5] Ramachndran,V.S, (1981)"Influence of Superplasticisers on hydration of Cement" Third International Conference on Polymers in Concrete.

[6] H Okamura and K Ozawa, (1995) 'Mix Design for SelfCompacting Concrete'. Concrete Library of JSCE, pp. 107-120.

\section{CODE REFERENCE}

[1] IS 10262:2009, "Recommended Guidelines for Concrete Mix Design".

[2] IS 383:1970, "Specification for coarse and fine aggregates from natural sources for concrete".

[3] IS 9103:1999, "Concrete Admixtures - Specification".

[4] IS 12269:1987, "Specification for 53 grade ordinary Portland cement". 